\title{
Clinical Trials with Ampicillin in Typhoid Fever and Paratyphoid A
}

\author{
L. MANRÍQUEZ,* M.D.; M. SALCEDO, $\dagger$ M.D. ; J. M. BORGOÑO, $\dagger$ M.D. ; E. MARZULLO,* M.D. \\ R. KRALJEVIĆł M.D. ; L. PAREDES,§ M.D. ; R. VALDIVIESO, $\|$ M.D.
}

Brit. med. F., 1965, 2, 152-153

At the present time chloramphenicol is the drug of choice for the treatment of acute typhoid and paratyphoid fever. The death rate of typhoid fever has been reduced from $10 \%$ to $0.5 \%$ in our hands. Severe complications are now less frequent; this way elimination of the infection relies upon the normal temperature within an average of five days. This excellent antibiotic, however, has the disadvantage of acting bacteriostatically, and in this way elimination of the infection relies upon the normal bodily defensive mechanisms of the patient. This mode of action has caused a considerable number of convalescent carriers, temporary or permanent (Jersild et al., 1959 ; Erlik and Reitler, 1960), and a high figure of recurrences (10\% to $18 \%$ ) according to our own experience (Kraljević et al., 1952,1957 ) and that of others (Smadel et al., 1949 ; El Ramli, 1953 ; Meneghello et al., 1954 ; Watson, 1957 ; Lantin et al., 1963). Furthermore, treatment with chloramphenicol is not without risks. There is the "impression," which is not well supported by documentation, that the poor response to chloramphenicol which is observed in some cases could well be due to a lower sensitivity of some strains of Salmonella typhi and $S$. paratyphi to the antibiotic.

It was hoped that the disadvantage of chloramphenicol in the treatment of typhoid and paratyphoid fever could be eliminated by the use of an antibiotic, such as ampicillin ( $\alpha$-amino-benzylpenicillin; Penbritin). This semi-synthetic penicillin has a higher activity in vitro than that of chloramphenicol against the various strains of salmonellae (Brown and Acred, 1961 ; Rolinson and Stevens, 1961 ; Bullock, 1963 ; Pettersson et al., 1964), and with a considerable bactericidal activity (Rolinson and Stevens, 1961 ; Kaye et al., 1963). Furthermore, tests in animals and in humans have demonstrated its lack of toxicity (Brumfitt et al., 1962 ; Ross et al., 1962 ; Klein and Finland, 1963).

This paper reports our experience of the treatment of typhoid and paratyphoid fever with ampicillin.

\section{Material and Method}

Twenty-five cases of typhoid fever and three cases of paratyphoid A fever were treated with ampicillin; the patients were admitted to the Hospital of Infectious Diseases and to the Service C of Medicine at the Hospital Jose Joaquin Aguirre between 22 November 1962 and 7 November 1963. They were 11 to 35 years of age, they had not been previously treated with any antibiotic, and their illness was of less than 15 days' standing.

In all cases the clinical diagnosis was confirmed by laboratory tests (Table I), with isolation of the causative organism (blood culture and stool culture) in $86 \%$ of the cases.

\footnotetext{
* Doctor of the Chair C of Medicine, School of Medicine, University of Chile, Santiago, Chile.

+ Doctor of the Chair of Infectious Diseases, School of Medicine, University of Chile, Santiago, Chile.

$\ddagger$ Professor of the Chair of Infectious Diseases, School of Medicine, University of Chile, Santiago, Chile.

$\$$ Professor of Microbiology, School of Medicine, University of Chile, Santiago, Chile.

II Professur of the Chair C of Medicine, School of Medicine, University of Chile, Santiago, Chile.
}

An equal number of males and females were treated, and the distribution of the cases according to age was related to the incidence of the disease (Table II). The distribution of cases in relation to days of illness prior to the beginning of treatment is shown in Table III.

Ampicillin was administered orally in daily doses of $75 \mathrm{mg}$./ $\mathrm{kg}$. body weight every six hours. The treatment lasted for a minimum of 14 days, with a minimum of eight afebrile days' treatment. If the temperature was not normal at the end of 10 days the treatment was considered as a failure.

\begin{tabular}{|c|c|c|}
\hline Methods & No. of Cases & $\%$ \\
\hline $\begin{array}{c}\text { Blood culture } \\
, \quad \# \quad+\text { agglutination reaction }\end{array}$ & $\begin{array}{l}5 \\
9\end{array}$ & $\begin{array}{l}17 \cdot 9 \\
32 \cdot 1\end{array}$ \\
\hline $\begin{array}{l}\text { tination" reaction } \\
\text { Stool culture + agglutination reaction } \\
\text { Agglutination reaction }\end{array}$ & $\begin{array}{l}7 \\
3 \\
4\end{array}$ & $\begin{array}{l}25 \cdot 0 \\
10 \cdot 7 \\
14 \cdot 3\end{array}$ \\
\hline Total & 28 & $100 \cdot 0$ \\
\hline
\end{tabular}

TABLE II.-Number of Cases per Age Group

\begin{tabular}{|c|c|c|c|c|c|c|}
\hline Age in Years: & $11-15$ & $16-20$ & $21-25$ & $26-30$ & $31-35$ & Total \\
\hline $\begin{array}{l}\text { No. of cases } \\
\text { Percentage }\end{array}$ & $\begin{array}{c}7 \\
25 \cdot 0\end{array}$ & $\begin{array}{l}10 \\
35 \cdot 7\end{array}$ & $21 \cdot 4$ & $\begin{array}{l}3 \\
10 \cdot 7\end{array}$ & $\begin{array}{l}2 \\
7 \cdot 2\end{array}$ & $\begin{array}{r}28 \\
100\end{array}$ \\
\hline
\end{tabular}

TABLE III.-Days of Illness Before the Beginning of Treatment

\begin{tabular}{|c|c|c|c|c|c|c|}
\hline Days: & $0-3$ & 4-6 & 7-9 & $10-12$ & 13-15 & Total \\
\hline $\begin{array}{ll}\text { No. of cases } & \ldots \\
\text { Percentage } & \ldots\end{array}$ & $\begin{array}{c}5 \\
17 \cdot 9\end{array}$ & $\begin{array}{c}4 \\
14 \cdot 3\end{array}$ & $\begin{array}{c}3 \\
10^{7} \cdot 7\end{array}$ & $\begin{array}{l}11 \\
39 \cdot 2\end{array}$ & $\begin{array}{c}5 \\
17.9\end{array}$ & $\begin{array}{r}28 \\
100\end{array}$ \\
\hline
\end{tabular}

The minimum inhibitory concentration of ampicillin against the isolated strains was determined by the serial-dilution technique in broth. The inoculum used was a dilution of $1: 4,000$ of a 20 -hour broth culture and the test was read after 20 hours' incubation at $37^{\circ} \mathrm{C}$. In the study of the blood levels obtained with ampicillin the serial-dilution technique of serum or plasma in broth was used with Sarcina lutea ATCC 9341 as test organism.

\section{Results}

There were no deaths and no complications of intestinal haemorrhage ; perforation of the intestine or cholecystitis was observed. The temperature became normal within the trial period of 10 days in $71 \%$ of the cases (Table IV). (It is important to note that $57 \%$ of the cases became afebrile before the seventh day of treatment.)

Ampicillin was considered to have failed in eight cases in which the temperature remained raised after 10 days' treat-

TABLE IV.-Normalization of Temperature

\begin{tabular}{|c|c|c|c|c|c|c|}
\hline \multirow{2}{*}{\multicolumn{2}{|c|}{ Days: }} & \multicolumn{2}{|c|}{1} & \multirow[b]{2}{*}{ 7-9 } & \multirow[b]{2}{*}{$\begin{array}{l}\text { Not Normal } \\
\text { in } 10 \text { Days }\end{array}$} & \multirow[b]{2}{*}{ Total } \\
\hline & & $1-3$ & $4-6$ & & & \\
\hline $\begin{array}{l}\text { No. of cases } \\
\text { Percentage }\end{array}$ & $\ldots$ & $\begin{array}{l}1 \\
3 \cdot 6\end{array}$ & $\begin{array}{l}15 \\
53 \cdot 5\end{array}$ & $\begin{array}{c}4 \\
14 \cdot 3\end{array}$ & $\begin{array}{c}8 \\
28 \cdot 6\end{array}$ & $\begin{array}{r}28 \\
100\end{array}$ \\
\hline
\end{tabular}


ment. In four of these cases diarrhoea occurred during the course of treatment.

These results were compared with those obtained in a group of 20 patients with the same degree of infection as the ampicillin-treated patients. This latter group received chloramphenicol at a dosage of $25 \mathrm{mg}$. $/ \mathrm{kg}$. body weight a day until the temperature had been normal for two days. The daily dose was then decreased to $12.5 \mathrm{mg}$. $/ \mathrm{kg}$. for a minimum of eight afebrile days, the minimum total treatment being 14 days. In 17 of the cases apyrexia was obtained before the tenth day of treatment, and three patients became afebrile on the tenth to twelfth days of treatment.

In the successful ampicillin cases an improvement was observed in the general condition of the patient, with disappearance of asthenia and improvement of appetite even before the temperature became normal. The condition of the patients who failed on ampicillin did not deteriorate. Attention should be drawn to the fact that splenomegaly was reduced both in the cases of success and in the cases of failure with ampicillin.

The patients were followed up in their homes 30 and 60 days after their discharge from hospital, and no recurrence was observed.

The drug was well tolerated. In one patient who developed nausea and vomiting on the eleventh day of treatment the daily dose of ampicillin was reduced to $37.5 \mathrm{mg} . / \mathrm{kg}$. $/$ day, and this side-effect disappeared. Maculo-papular exanthema of the rubella-type, especially on the trunk, appeared in five patients. The treatment was not suspended, and the eruption disappeared at the end of five or six days.

In Vitro Sensitivity of the Isolated Strains and Serum Concentrations of Ampicillin.-A study was carried out on the minimum inhibitory concentrations of ampicillin against 13 of the isolated strains of S. typhi. In 18 of the 28 patients treated the serum concentrations of the antibiotic obtained from samples taken three hours after the administration of the first dose of $18.75 \mathrm{mg}$. $/ \mathrm{kg}$. (equivalent to one-quarter of the total daily dose) are shown in Table V, the cases of successful treatment being separated from the failures. Ten of the 13

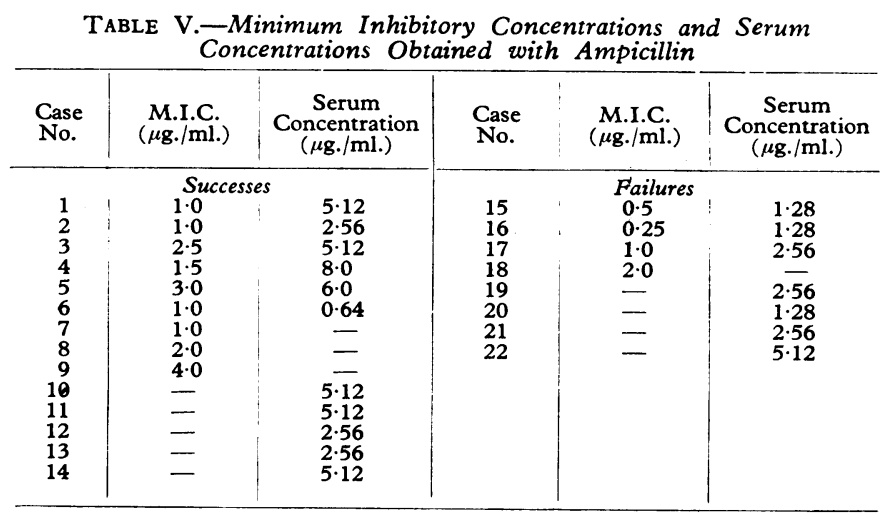

strains of $S$. typhi studied were inhibited by $2 \mu \mathrm{g} . / \mathrm{ml}$. or less. This agrees with the findings of Bullock (1963), Kaye et al. (1963), and Pettersson (1964). It should be noted, however, that the strains with the highest minimum inhibitory concentrations $(2.5,3$, and $4 \mu \mathrm{g} . / \mathrm{ml}$. respectively) occurred in cases in which therapeutic success was obtained. The concentrations obtained in the blood are similar to those obtained by others using the same doses of the antibiotic (Ross et al., 1962 ; Bullock, 1963 ; Klein and Finland, 1963). Both minimum inhibitory concentration and serum concentrations of ampicillin were studied in nine patients. In eight of them, of which five were successfully treated and three failed to respond to ampicillin therapy, serum concentrations of the drug were clearly higher than the corresponding minimum inhibitory concentrations.

\section{Conclusions}

In the light of the results obtained, ampicillin seems to be a useful antibiotic which is well tolerated in the treatment of typhoid and paratyphoid fever. It is somewhat less effective than chloramphenicol, but could be used in the treatment of these infections when chloramphenicol is contraindicated. This limited trial demonstrated that ampicillin gave successful results in $71 \%$ of the cases treated. We believe that it is necessary to treat a larger number of cases before definite conclusions can be drawn.

The failures could not be clearly explained by the serum conzentrations obtained and the minimum inhibitory concentration for the given organism. It is clear, however, that since we measured the blood levels only at the beginning of treatment we cannot attribute these failures to faulty absorption due to diarrhoea.

In order to confirm the fact that there were no recurrences in the group of 28 patients treated with ampicillin, larger numbers of patients would have to be observed so as to eliminate the possibility of unforeseen relapses.

A trial is now being organized to study the efficacy of intramuscular ampicillin from a clinical and bacteriological viewpoint, particularly in relation to blood cultures and stool cultures.

\section{Summary}

Twenty-eight patients with typhoid or paratyphoid fever were treated with ampicillin. Success was achieved in $71 \%$ of the cases, with the temperature returning to normal before the tenth day of treatment. These results are less favourable than those obtained with chloramphenicol. There were no recurrences after ampicillin therapy, and the drug was well tolerated. A possible manifestation of hypersensitivity (maculo-papular exanthema) was observed in five patients.

\section{REFERENCES}

Brown, D. M., and Acred, P. (1961). Brit. med. F., 2, 197.

Brumfitt, W., Percival, A., and Carter, M. J. (1962). Lancet, 1, 130.

Bullock, W. E. (1963). Amer. F. med. Sci., 246, 42.

El Ramli, A. H. (1953). Lancet, 1, 927.

Erlik, D., and Reitler, R. (1960). Ibid., i, 1216.

Jersild, T., Neukirch, E., Raun, J., Riwerts-Eriksen, K., and Tulinius,

Kaye, D., Merselis, J. G., and Hook, E. W. (1963). New Engl. F. Med., Klein 269, 1084.

Klein, J. O., and Finland, M. (1963). Amer. F. med. Sci., 245, 544. Ro;as, M., and Jiménez, L. (1952). Rev. méd. Chile, 80, 521 ., H., Ibid., 85, 525. H., Moya, H., Flores, L., and Salcedo, M. (1957). Lantin, P. T., Gerónimo, A., and Calilong, V. (1963). Amer. F. med.

Meneghello, J., Undurraga, O., and Raimann, A. (1954). Rev. chil. Pediat., 25, 119.

Pettersson, T., Klemola, E., and Wager, O. (1964). Acta med. scand., $175,185$.

Rolinson, G. N., and Stevens, S. (1961). Brit. med. F., 2, 191. Ross, S., Lovrien, E. W., Zaremba, E. A., Bourgeois, L., and Puig, J. R.

129. Watson, K. C. (1957). Amer. f. trop. Med. Hyg., 6, 72. 